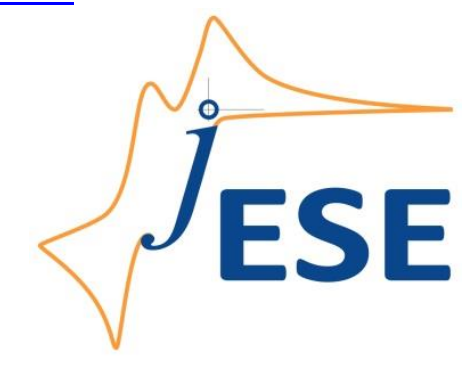

Open Access : : ISSN 1847-9286

www.jESE-online.org

Original scientific paper

\title{
Decolorization of industrial wastewater using electrochemical peroxidation process
}

\author{
Elin Marlina ${ }^{1, 凶}$, Purwanto Purwanto ${ }^{2}$ and Sudarno Sudarno ${ }^{3}$ \\ ${ }^{1}$ Doctoral Program of Environmental Science, School of Postgraduate Studies, Universitas \\ Diponegoro, Semarang, Indonesia \\ ${ }^{2}$ Department of Chemical Engineering, Faculty of Engineering, Universitas Diponegoro, Semarang, \\ Indonesia \\ ${ }^{3}$ Department of Environmental Engineering, Faculty of Engineering, Universitas Diponegoro, \\ Semarang, Indonesia \\ Corresponding author: ${ }^{凶}$ elin.marlina95@gmail.com
}

Received: June 8, 2021; Accepted: December 3, 2021; Published: December xx, 2021

\begin{abstract}
In this study, decolorization of wastewater samples taken from the paper industry is investigated using an electrochemical peroxidation process. The electrochemical peroxidation process is a part of electrochemical advanced oxidation processes, which is based on the Fenton's chemical reaction, provided by the addition of external $\mathrm{H}_{2} \mathrm{O}_{2}$ into the reaction cell. In this study, iron is used as anode and graphite as cathode placed at the fixed distance of $30 \mathrm{~mm}$ in a glass reaction cell. The cell was filled with the solution containing wastewater and sodium chloride as the supporting electrolyte. Factors of the process such as $\mathrm{pH}$, current intensity, hydrogen peroxide concentration, and time of treatment were studied. The results illustrate that all these parameters affect efficiencies of dye removal and chemical oxygen demand (COD) reduction. The maximal removal of wastewater contaminants was achieved under acid $(\mathrm{pH} 3)$ condition, with the applied current of $1 \mathrm{~A}$ and hydrogen peroxide concentration of $0.033 \mathrm{M}$. At these conditions, decolorization process efficiency reached 100 and $83 \%$ of COD removal after 40 minutes of wastewater sample treatment. In addition, the electrical energy consumption for wastewater treatment by electrochemical peroxidation was calculated, showing an increase as the current intensity of the treatment process was increased. The obtained results suggest that the electrochemical peroxidation process can remove dye compounds and chemical oxygen demand (COD) from industrial wastewaters with high removal efficiency.
\end{abstract}

\section{Keywords}

Paper industry wastewater; electrochemical peroxidation; Fenton's reaction; decolorization efficiency; chemical oxygen demand 


\section{Introduction}

Dyes are widely used in various industries such as paper, textile, leather tanning, and printing industries, causing environmental pollution, especially water pollution. Five million quintals of azo dyes are produced each year worldwide, which constitute half of the total dyes produced [1,2].

The paper industry is a type of industry that uses a lot of water and many active ingredients, including dyes [2]. Therefore, besides some active compounds, the wastewater may contain different dyes. Since dye wastewater becomes a problem for the environment, the industry is forced to carry out treatment procedure(s) that can overcome this problem [3-5]. In this context, the removal of active compounds measured as chemical oxygen demand (COD), and decolorization of wastewater, are considered crucial because many dyes and decomposition products are poisonous. Elimination of colours in wastewaters, especially industrial wastewaters, is essential because colour could severely affect the water-living system.

The electro-Fenton's processing is a part of electrochemical advanced oxidation processes (EAOPs) technology. The EAOP process itself pertains to the advanced oxidation processes (AOPs) developed mostly over the last decade by using clean, efficient, and economical processing in removing pollutants in water [6-8]. On the other hand, EAOPs form a group of emerging technologies, where pollutant removal is based on the Fenton's chemical reaction. There are two types of processing, the first one is carried out with the addition of external $\mathrm{H}_{2} \mathrm{O}_{2}$, and the second involves internal regeneration of $\mathrm{H}_{2} \mathrm{O}_{2}$ [3]. The electrochemical peroxidation process is part of the first type, where a sacrificial iron or steel anode is used for electro-generation of $\mathrm{Fe}^{2+}$ ions by anodic dissolution. $\mathrm{H}_{2} \mathrm{O}_{2}$ is externally added to the treated solution to degrade organic pollutants with hydroxyl radicals $(\bullet \mathrm{OH})$ generated by Fenton's reaction [9-11].

The electrochemical peroxidation process has a similar mechanism to electrocoagulation, but better COD removal results were obtained with the addition of $\mathrm{H}_{2} \mathrm{O}_{2}$ [12-14]. Several studies have reported that COD of coke wastewater can be removed up to $90 \%$ by electrochemical peroxidation, whereas by electrocoagulation, up to $30 \%$ was removed only [13].

During past decades, the electrochemical peroxidation process showed a promising perspective in treating several kinds of dyes that contaminated water, causing pollution. In this experimental study, the application of the electrochemical peroxidation process for the decolorization of paper industrial wastewater was explored. Based on previous studies that showed successful decolorization by the Fenton's oxidative processes, in the present study, the opportunity of decolorization of paper industry wastewater has been investigated using the Fenton's oxidation processing. This study will explore the effects of various operating parameters, including the initial $\mathrm{pH}$ of the solution, applied current strength, the dosage of $\mathrm{H}_{2} \mathrm{O}_{2}$, and treatment time on decolorization and $\mathrm{COD}$ removal. Energy consumption was also studied to determine the most efficient process conditions for paper industry wastewater treatment. Positive results of this research should increase the knowledge of those responsible for wastewater treatment in the paper industry.

\section{Experimental}

\section{Materials and chemicals}

Paper wastewater samples were taken from the equalization tank effluent in the paper mill plant in Kudus, District Central Java Province, Indonesia. The physicochemical characterization of these effluents showed COD of $240 \mathrm{mg} / \mathrm{L}, \mathrm{pH} 6.8$ and dark yellow colour. $\mathrm{H}_{2} \mathrm{O}_{2}(30 \%, \mathrm{w} / \mathrm{w}), \mathrm{H}_{2} \mathrm{SO}_{4}$, and 
$\mathrm{NaCl}$ were obtained from Merck, Germany. All chemicals were of analytical grade and directly used without purification process.

The experiments were performed at room temperature, using the open single-cell glass reactor with dimensions of $12 \times 10 \times 12 \mathrm{~cm}(1.4 \mathrm{~L}$ ) (Figure 1 ). The reactor is equipped with two vertical plate electrodes, graphite as cathode and iron plate as anode with $376.2 \mathrm{~cm}^{2}$ of the total surface area $(10 \times 9 \times 0.3 \mathrm{~cm})$. Two electrodes were put at a distance of $3 \mathrm{~cm}$ and connected to a DC power supply (MDS PS-305DM). A magnetic stirrer was used to homogenize the electrolyte solution. Distilled water was used throughout this experiment.

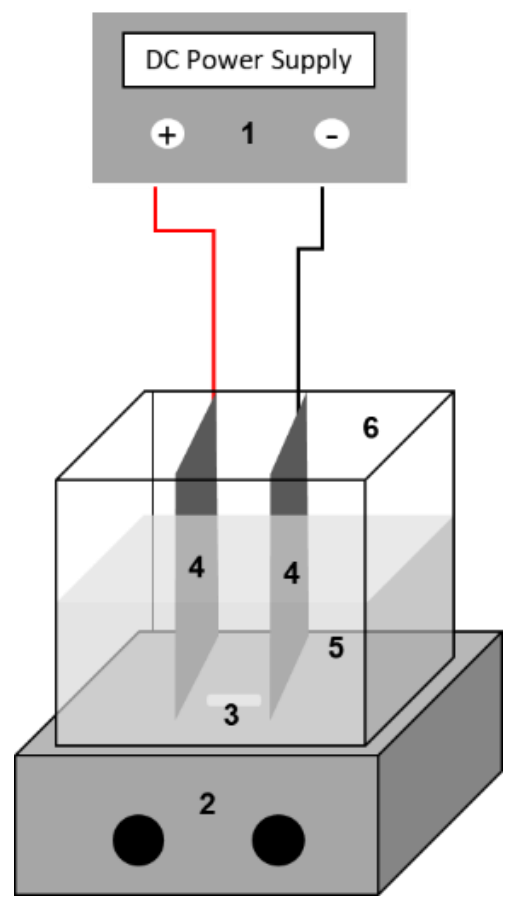

Figure 1. Glass reactor setup: DC power supply (1); magnetic stirrer (2); magnetic bar-stirrer (3); electrodes (4); solution (5)

\section{Experimental procedures}

The electrodes were cleaned before the experiment by soaking in $0.5 \mathrm{M} \mathrm{H}_{2} \mathrm{SO}_{4}$ solution for 15 minutes. One litre of wastewater solution was put into the reactor, together with $0.585 \mathrm{~g}$ of $\mathrm{NaCl}$ $(0.01 \mathrm{M})$ as the electrolytic support, and $\mathrm{H}_{2} \mathrm{O}_{2}$ was added externally. The batch experiments were carried out in a homogeneous solution. To decrease the $\mathrm{pH}$ value, $0.5 \mathrm{M} \mathrm{H}_{2} \mathrm{SO}_{4}$ was added stepwise to reach the desired $\mathrm{pH}$ value. $15 \mathrm{ml}$ of the treated solution were taken at regular intervals and filtered before further analysis.

A water quality meter (Trans Instruments HP9000) was used to test solution pH values. COD samples were tested using a closed reflux titrimetric method based on SNI-06-6989.2-2009 and colour tested using SNI 6989.80:2011. A double-beam UV-vis spectrophotometer (Shimadzu UV1700 , Japan) equipped with a $10 \mathrm{~mm}$ quartz cell was used to measure colour and COD concentration by determining absorbance at $\lambda=450-465 \mathrm{~nm}$ for colour and $600 \mathrm{~nm}$ for COD.

The removal efficiency was determined by the following equation:

$$
E f=\frac{c_{\mathrm{o}}-c_{\mathrm{s}}}{c_{\mathrm{o}}} 100
$$

where $C_{0}$ and $C_{S}$ refer to initial dye concentration and dye concentration at time $t$, respectively. The electrical energy consumption for a liter of the solution was calculated by:

$E=$ Vit 
Here $E$ is the energy consumption in $\mathrm{J}, V$ is the cell voltage in $\mathrm{V}, l$ is the current in $\mathrm{A}$, and $t$ is the reaction time in $\mathrm{s}[15]$.

\section{Results and discussion}

The electrochemical peroxidation is one kind of electro-Fenton's process, where the anode is used for electro-generation of $\mathrm{Fe}^{2+}$ ions according to:

$\mathrm{Fe} \rightarrow \mathrm{Fe}^{2+}+2 \mathrm{e}^{-}$

$\mathrm{H}_{2} \mathrm{O}_{2}$ is added from outside to degrade organic pollutants with hydroxyl radicals $(\bullet \mathrm{OH})$ created from the Fenton's reaction:

$\mathrm{Fe}^{2+}+\mathrm{H}_{2} \mathrm{O}_{2} \rightarrow \mathrm{Fe}^{3+}+\mathrm{OH}^{-}+\cdot \mathrm{OH}$

$\mathrm{Fe}^{3+}$ ions formed by Fenton's reaction (4) are continuously reduced at the cathode according to:

$\mathrm{Fe}^{3+}+\mathrm{e}^{-} \rightarrow \mathrm{Fe}^{2+}$

In this process, a part of $\mathrm{Fe}^{3+}$ ions formed by the Fenton's reaction (4) precipitates as $\mathrm{Fe}(\mathrm{OH})_{3}$ by the reaction, which depends on $\mathrm{pH}$ and the applied current value. These deposits can catalytically decompose $\mathrm{H}_{2} \mathrm{O}_{2}$ to $\mathrm{O}_{2}$ but also be an alternative for the removal of organic pollutants by coagulation [9].

\section{Effect of initial solution $\mathrm{pH}$}

As pointed out in previous studies, the $\mathrm{pH}$ of the solution is one of the significant factors affecting the electrochemical work process [16-18]. $\mathrm{pH}$ value determines the speciation of iron in solution, and $\mathrm{pH} 3$ was found as the optimum value for dye degradation by electro-Fenton's process. In acidic conditions, iron anode dissolves as $\mathrm{Fe}^{2+}$ ions in water according to reaction (3), which will be the catalyst to produce $\bullet \mathrm{OH}$ radicals with the added $\mathrm{H}_{2} \mathrm{O}_{2}$ according to reaction (4). At $\mathrm{pH} 3$, iron ions $\left(\mathrm{Fe}^{2+}\right)$ and hydrogen peroxide will remain stable. Therefore, the Fenton's reaction can occur perfectly under this condition $[20,21]$.

As presented in Figure 2, $100 \%$ decolorization in acidic conditions $(\mathrm{pH} 3)$ was obtained after 60 min of treatment at $0.5 \mathrm{~A}$, when the blue colour changed into clear watercolor. On the other hand, when $\mathrm{pH}$ was 6.8 (normal $\mathrm{pH}$ ), $99 \%$ decolorization was obtained only at the maximum electrolysis time of $120 \mathrm{~min}$.

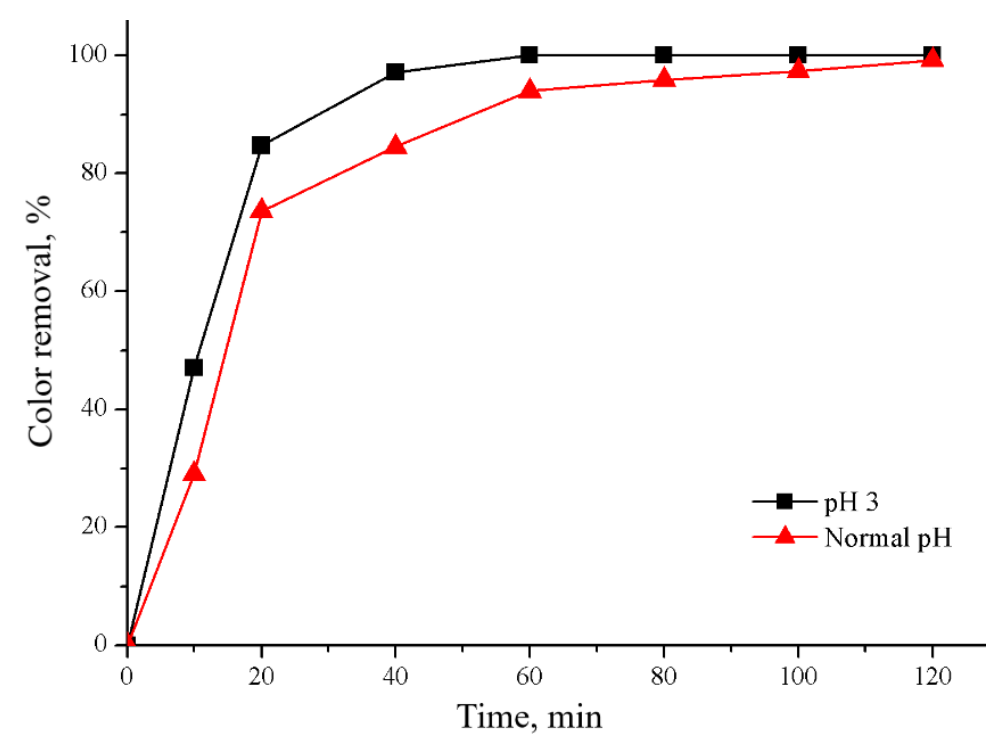

Figure 2. Decolorization efficiency vs. treatment time at $0.5 \mathrm{~A}$ of wastewater samples containing $0.033 \mathrm{M} \mathrm{H}_{2} \mathrm{O}_{2}$ and $0.01 \mathrm{M} \mathrm{NaCl}$, at $\mathrm{pH} 3$ and 6.8 
COD levels were also tested at two $\mathrm{pH}$ values, and Figure 3 presents the results of these experiments. By acidifying the solution, COD was removed up to $\sim 65 \%$ in $120 \mathrm{~min}$. COD removal started immediately with a decrease in COD value, reaching $100 \mathrm{mg} / \mathrm{L}$ after $20 \mathrm{~min}$ of treating (140 mg/L removed). After $20 \mathrm{~min}$, COD removal did not increase significantly, which can be due to the $\mathrm{pH}$ increase of the solution to 5 . Previous research on optimal electrochemical peroxidation processes in acidic conditions showed that increased solution pH significantly inhibited COD removal $[18,20]$. The electrochemical peroxidation process removal decreases rapidly at higher $\mathrm{pH}$ values, especially at $\mathrm{pH}$ higher than 5 [19]. An increase of $\mathrm{pH}$ during the electrochemical peroxidation process leads to the domination of the electrocoagulation process due to the conversion of $\mathrm{Fe}^{2+}$ and $\mathrm{Fe}^{3+}$ to $\mathrm{Fe}(\mathrm{OH})_{\mathrm{n}}[21]$.

In acidic solutions, $\mathrm{pH}$ increased significantly during COD removal. As seen in Figure 3, COD removal slowed down after $20 \mathrm{~min}$ (pH 4.3 and removal efficiency $59 \%$ ). After $120 \mathrm{~min}$, however, $\mathrm{pH} 9.21$ and $62 \%$ removal efficiency were reached. This reinforces the common statement of previous researchers that the best removal in the electrochemical peroxidation process is carried out in acidic conditions [21-23].

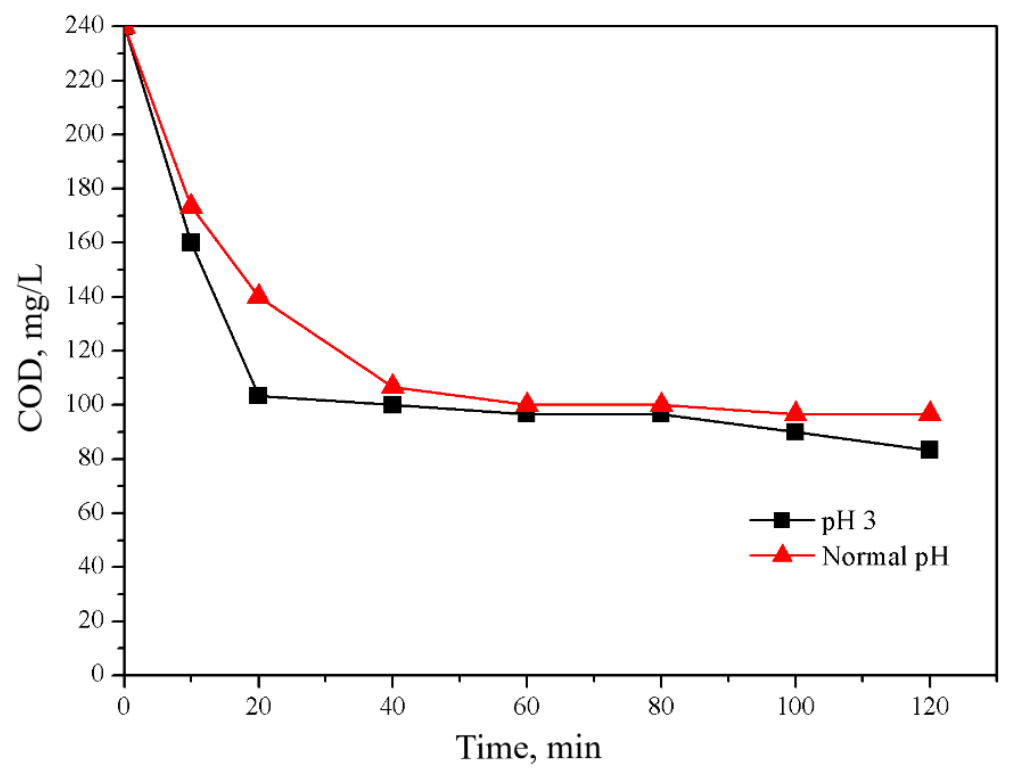

Figure $3 \mathrm{COD}$ concentration vs. treatment time at $0.5 \mathrm{~A}$ of wastewater samples containing $0.033 \mathrm{M} \mathrm{H}_{2} \mathrm{O}_{2}$ and $0.01 \mathrm{M} \mathrm{NaCl}$, at different $\mathrm{pH}$

\section{Effect of $\mathrm{H}_{2} \mathrm{O}_{2}$}

As the main source of hydroxyl radicals, the initial concentration of $\mathrm{H}_{2} \mathrm{O}_{2}$ plays an important role in the electrochemical peroxidation process of oxidizing the pollutants. It has already been found that the removal efficiency increases with the increasing concentration of $\mathrm{H}_{2} \mathrm{O}_{2}$ in the solution $[13,22,24-26]$. As presented in Figure 4, increasing the initial concentration of $\mathrm{H}_{2} \mathrm{O}_{2}$ in wastewater solution containing $0.585 \mathrm{~g} \mathrm{NaCl}, \mathrm{pH} 3$, improves colour removal. In the absence of $\mathrm{H}_{2} \mathrm{O}_{2}$, where only the electrocoagulation process is operative, the rate of colour removal after $10 \mathrm{~min}$ was $19 \%$, while after the addition of 0.0165 $\mathrm{M} \mathrm{H}_{2} \mathrm{O}_{2}$, colour removal after 10 min increased to even $30 \%$. This is due to the presence of more $\mathrm{OH} \bullet$ provided by Fenton's reaction (4) in the reactor, which oxidized more organic compounds. The further increase of $\mathrm{H}_{2} \mathrm{O}_{2}$ concentration to $0.033 \mathrm{M}$ and $0.0495 \mathrm{M}$ improved decolorization after $10 \mathrm{~min}$ to $43 \%$ and $79 \%$, respectively. Note that for the highest concentration of $0.0495 \mathrm{M} \mathrm{H}_{2} \mathrm{O}_{2}$, full depolarization is 
reached within $20 \mathrm{~min}$. This refinement is related to the generation of more hydroxyl radical species in the presence of increasing amounts of hydrogen peroxide [27].

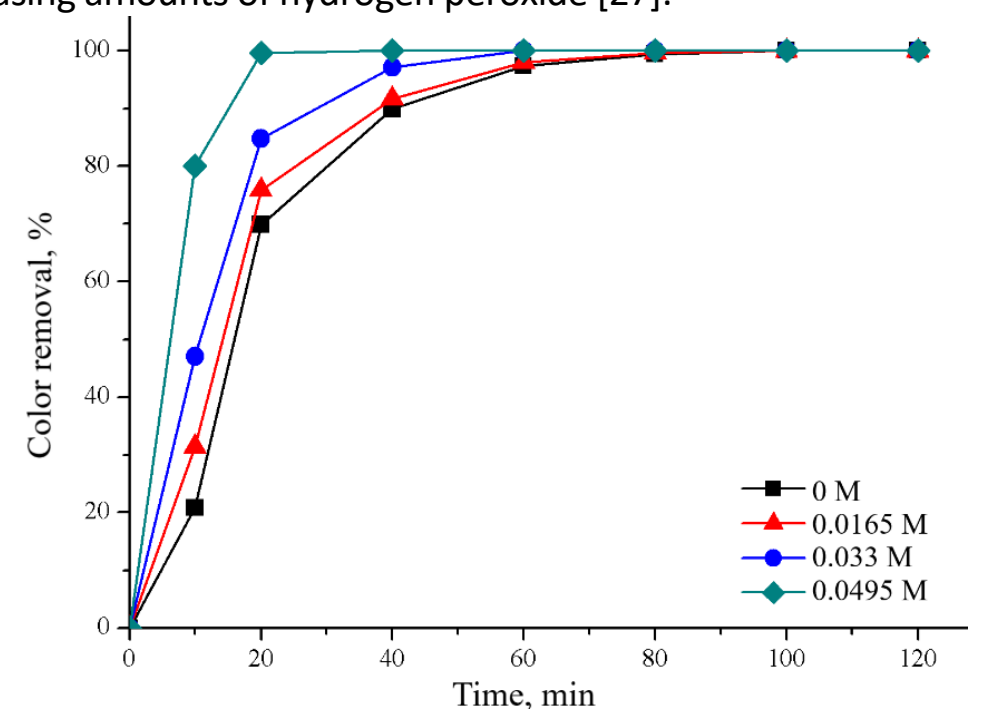

Figure 4. Decolorization efficiency vs. treatment time at $0.5 \mathrm{~A}$ of wastewater samples containing $0.01 \mathrm{M} \mathrm{NaCl}, \mathrm{pH}=3$ and different concentrations of $\mathrm{H}_{2} \mathrm{O}_{2}$

The effect of $\mathrm{H}_{2} \mathrm{O}_{2}$ concentration on $\mathrm{COD}$ removal was evaluated at the constant current of $0.5 \mathrm{~A}$ and started with the solution of $\mathrm{pH} 3$. The results are presented in Figure 5 , where it is seen that in the absence of $\mathrm{H}_{2} \mathrm{O}_{2}$, the rate of $\mathrm{COD}$ removal is $13 \%$ since only electrocoagulation is effective in this case. It has already been revealed by previous researchers that the electrocoagulation process has not a significant effect on COD removal [28]. The mechanism of COD removal in the electrocoagulation process is going exclusively through the adsorption process by $\mathrm{Fe}(\mathrm{OH})_{3}$. At $\mathrm{H}_{2} \mathrm{O}_{2}$ concentration of $0.0165 \mathrm{M}$, however, COD was reduced by $30 \%$ in $20 \mathrm{~min}$, and this is due to hydroxyl radicals produced in the electro peroxidation process caused by added $\mathrm{H}_{2} \mathrm{O}_{2}$ [9,29-31]. Figure 5 indicates that increased concentration of $\mathrm{H}_{2} \mathrm{O}_{2}$ improves $\mathrm{COD}$ removal since efficiencies after 20 and 120 min were increased from 29.2 to $63.9 \%$ for $0.0165 \mathrm{M} \mathrm{H}_{2} \mathrm{O}_{2}, 33.3$ to $65.3 \%$ for $0.033 \mathrm{M}$ and 40.2 to $69.4 \% 0.0495 \mathrm{M} \mathrm{H}_{2} \mathrm{O}_{2}$.

It is also seen in Figure 5 that after $20 \mathrm{~min}, \mathrm{COD}$ removal increased only slightly for all samples, which is due to the increasing $\mathrm{pH}$ value to 5 in $20 \mathrm{~min}$, and 11.2 in $120 \mathrm{~min}$.

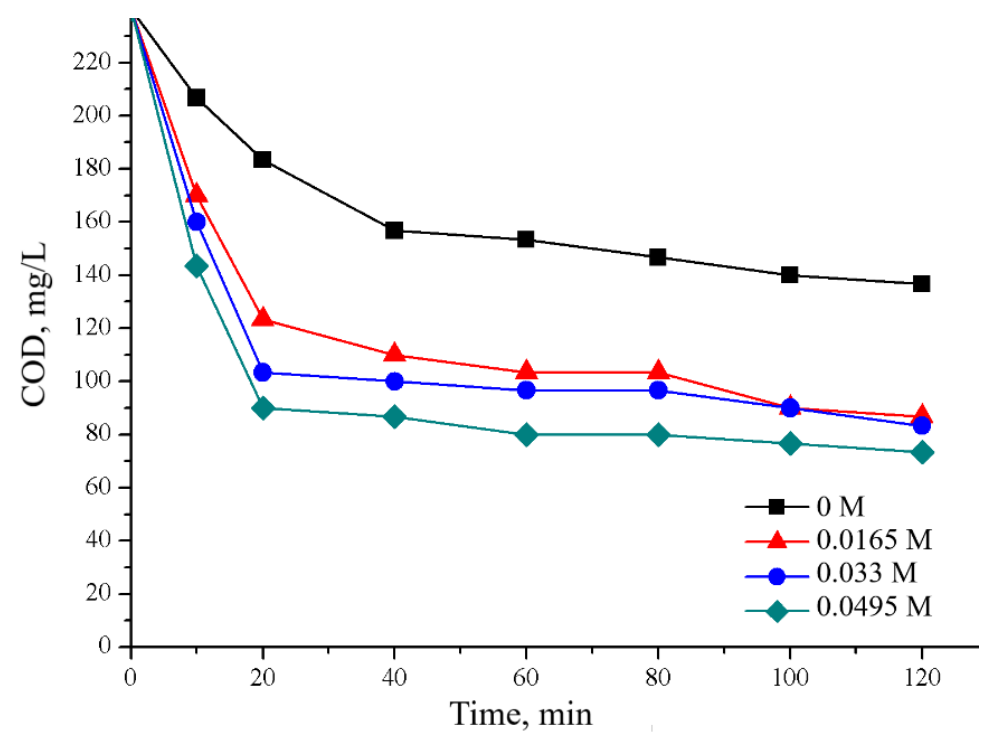

Figure 5. $\mathrm{COD}$ removal vs. treatment time at $0.5 \mathrm{~A}$ of wastewater samples containing $0.01 \mathrm{M}$ $\mathrm{NaCl}, \mathrm{pH} 3$, and different concentrations of $\mathrm{H}_{2} \mathrm{O}_{2}$ 
This suggests that uncontrolled $\mathrm{pH}$ conditions affect the process significantly. The performance of the electrochemical peroxidation process is optimal in acidic solutions, where generation of iron ions would occur and react by the classic Fenton's reaction, developing $\mathrm{OH} \bullet$ as efficient oxidizers of organic compounds [9].

\section{Effect of applied current}

The effect of applied current intensity on the electrochemical peroxidation process was also tested. The influence of different applied current intensities on colour and COD degradations was evaluated in $1 \mathrm{~L}$ of wastewater solution with $0.05 \mathrm{M} \mathrm{NaCl}, \mathrm{pH} 3$ and $0.033 \mathrm{M} \mathrm{H}_{2} \mathrm{O}_{2}$. The obtained results are shown in Figures 6 and 7.

Figure 6 shows that different processing results are obtained at different applied current intensities. Generally, colour removal increased with increasing current strength. At $0.3 \mathrm{~A}$, the results showed $10 \%$ decolorization after 10 minutes, while $99 \%$ degradation was observed after 120 minutes. At higher currents of 0.75 and $1 \mathrm{~A}$, respectively, the colour removals reached 79 and $90 \%$ after 10 minutes and $100 \%$ after 120 minutes of treatment. Better colour degradations observed at higher currents may be due to the fact that an increased amount of oxidized iron is generated from the anode at higher currents [32]. On the other side, the high current density is a trigger factor for the oxygen reduction process, which serves to regenerate hydrogen peroxide at the cathode [29,33-35]. The high currents cause an increase in the amount of $\mathrm{OH} \bullet$ so that the degradation process is more reactive and responsive [25]. In addition to the increasing amount of $\mathrm{OH} \bullet$ in solution, the use of high currents also causes the regeneration of iron ions, and the Fenton process's efficiency also increases [36].

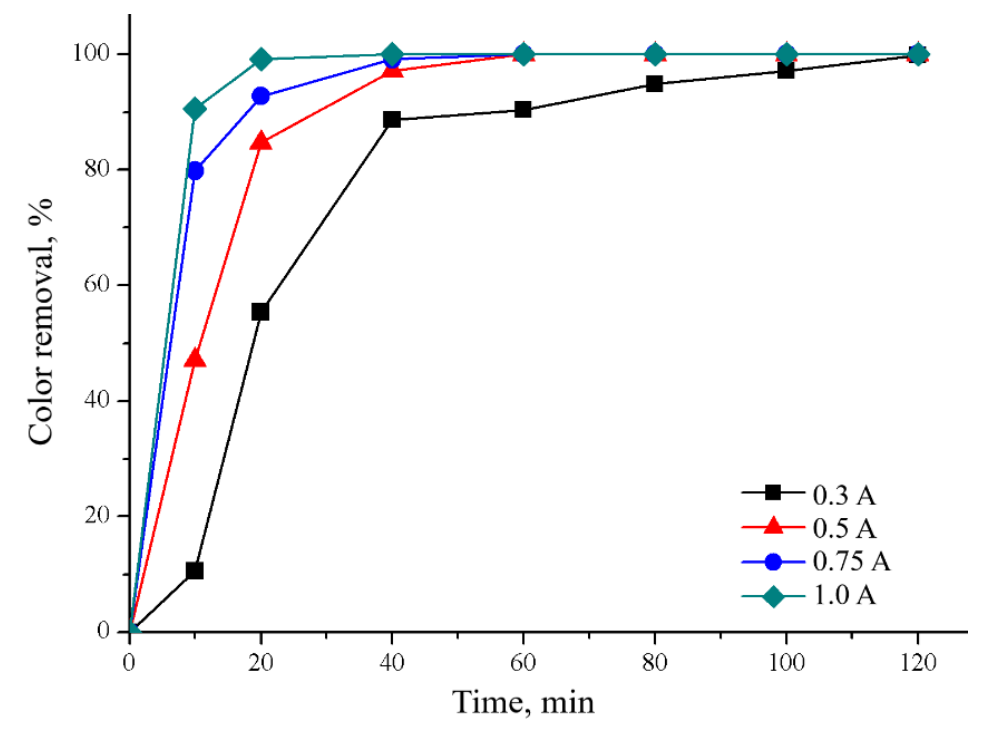

Figure 6. Decolorization efficiency vs. treatment time of wastewater samples containing 0.033 $\mathrm{M} \mathrm{H}_{2} \mathrm{O}_{2}$ and $0.05 \mathrm{M} \mathrm{NaCl}, \mathrm{pH} 3$ at different current intensities

Figure 7 shows that a decrease in COD concentration with treatment time was observed at all current intensities. For the highest current of $1.0 \mathrm{~A}$, there is a significant reduction of COD in $40 \mathrm{~min}$, leaving the lowest COD concentration of $40 \mathrm{mg} / \mathrm{L}$ with a removal ratio of $83 \%$. At $0.3 \mathrm{~A}$, the lowest removal efficiency was obtained, where the removal ratio reached only 54 and $61 \%$ in 120 min, with the remaining COD content $110 \mathrm{mg} / \mathrm{L}$ in $40 \mathrm{~min}$. When applying the current intensity of $1 \mathrm{~A}$, there is a decrease in the COD removal efficiency in the treatment period of 60 to $120 \mathrm{~min}$. This is probably due to the increase in the amount of $\mathrm{Fe}^{2+}$ ions released at the anode through the electrolysis time, 
thereby reducing the efficiency electro-Fenton's process [18]. This study has similarities with previous studies [38-40], which showed that an excessive current or voltage would cause a decrease in COD removal.

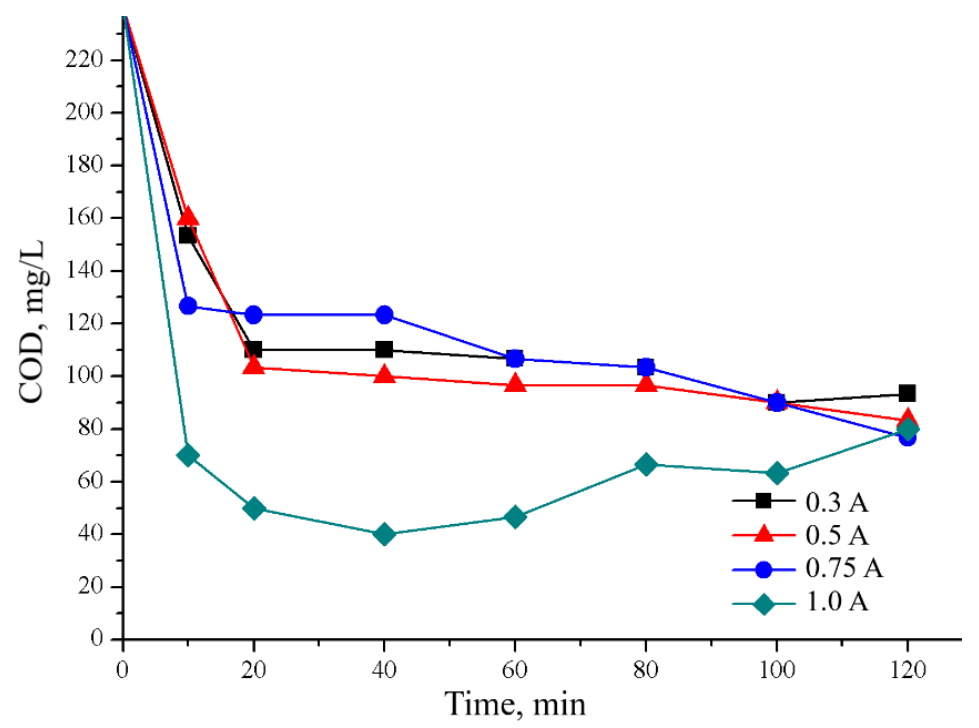

Figure $7 \mathrm{COD}$ concentration vs. treatment time of wastewater samples containing $0.033 \mathrm{M}$ $\mathrm{H}_{2} \mathrm{O}_{2}, 0.05 \mathrm{M} \mathrm{NaCl}, \mathrm{pH} 3$ at different current intensities

On the other hand, high currents will increase energy consumption in the electrochemical process [37]. The energy consumption in the process was calculated by eq. (2), where electric voltages recorded after $120 \mathrm{~min}$ for current values between 0.3 and $1.0 \mathrm{~A}$ (Figure 7), were 7.2, 10.5, 14 and $15 \mathrm{~V}$, respectively. It is obvious from these values that rising currents caused rising voltage. According to eq. (2), energy consumption was calculated to be $15.6,37.8,75.6$ and $108 \mathrm{~kJ}$. The linear correlation between current, voltage, and energy consumption has already been investigated, giving similar results [15].

\section{Conclusions}

In this study, a detailed exploration of the electrochemical peroxidation treatment of paper industrial wastewater is described. It was found that process factors such as $\mathrm{pH}$, applied current, and concentration of added $\mathrm{H}_{2} \mathrm{O}_{2}$ significantly affect decolorization efficiency and COD removal from the paper wastewater solution. The following conclusions can be derived from the present study:

- The electrochemical peroxidation process is facilitated in an acid condition.

- Colour and COD removal continuously increased as $\mathrm{H}_{2} \mathrm{O}_{2}$ was added to the process up to the concentration of $0.0495 \mathrm{M}$.

- The current intensity influences colour and COD degradation in the electrochemical peroxidation process, where clear water was obtained for the current of $1 \mathrm{~A}$ in $20 \mathrm{~min}$ of treatment.

- The electrochemical peroxidation process can be used as an efficient operational process to remove colour and COD from paper industrial wastewater.

Acknowledgement: Authors thank Deputy for Strengthening Research and Development, Ministry of Research and Technology / National Research and Innovation Agency of the Republic of Indonesia for funding this research through PMDSU Research Grant 2020 contract: 647-02/UN7.6.1/PP/2020. 


\section{References}

[1] A. D. Bokare, R. C. Chikate, C. V. Rode, K. M. Paknikar, Applied Catalysis B 79(3) (2008) 270278. https://doi.org/10.1016/j.apcatb.2007.10.033

[2] G. Thompson, J. Swain, M. Kay, C. F. Forster, Bioresource Technology 77(3) (2001) 275-286. https://doi.org/10.1016/S0960-8524(00)00060-2

[3] E. Brillas, I. Sirés, M. A. Oturan, Chemical Reviews 109(12) (2009) 6570-6631. https://doi.org/10.1021/cr900136g

[4] C. A. Martınez-Huitle, E. Brillas, Applied Catalysis B 87(3-4) (2009) 105-145. https://doi.org/10.1016/i.apcatb.2008.09.017

[5] N. Klidi, F. Proietto, F. Vicari, A. Galia, S. Ammar, A. Gadri, O. Scialdone, Journal of Electroanalytical Chemistry 841 (2019) 166-171. https://doi.org/10.1016/i.jelechem.2019.$\underline{04.022}$

[6] N. Oturan, M. A. Oturan, in: Electrochemical Water and Wastewater Treatment, Chap. 8 (2018) 193-221. https://doi.org/10.1016/B978-0-12-813160-2.00008-0

[7] S. Loaiza-Ambuludi, M. Panizza, N. Oturan, A. Özcan, M. A. Oturan, Journal of Electroanalytical Chemistry 702 (2013) 31-36. https://doi.org/10.1016/i.jelechem. $\underline{2013.05 .006}$

[8] T. M. Do, J. Y. Byun, S. H. Kim, Catalysis Today 295 (2017) 48-55. https://doi.org/10.1016/ j.cattod.2017.05.016

[9] H. Lin, Removal of Organic Pollutants from Water by Electro-Fenton and Electro-Fenton like Processes, Ph.D. Thesis, Université Paris-Est, 2015.

[10] P. A. Diaw, N. Oturan, M. D. G. Seye, A. Coly, A. Tine, J.-J. Aaron, M. A. Oturan, Separation and Purification Technology 186 (2017) 197-206. https://doi.org/10.1016/j.seppur.2017. $\underline{06.005}$

[11] O. Iglesias, M. A. Fernández de Dios, T. Tavares, M. A. Sanromán, M. Pazos, Journal of Industrial and Engineering Chemistry 27 (2015) 276-282. https://doi.org/10.1016/j.jiec.2014.12.044

[12] M. J. Bashir, J. H. Lim, S. S. A. Amr, L. P. Wong, Y. L. Sim, Journal of Cleaner Production 208 (2020) 716-727. https://doi.org/10.1016/j.jclepro.2018.10.073

[13] F. Ozyonar, B. Karagozoglu, Separation and Purification Technology 150 (2015) 268-277. https://doi.org/10.1016/i.seppur.2015.07.011

[14] G. Selvabharathi, S. Adishkumar, J. R. Banu, Desalination and Water Treatment 156 (2019) 340-348. http://dx.doi.org/10.5004/dwt.2019.23935

[15] P. Rafiee, M. Hosseini, S. Ebrahimi, Reaction Kinetics, Mechanisms and Catalysis 131 (2020) 319-334. https://doi.org/10.1007/s11144-020-01846-0

[16] A. Baiju, R. Gandhimathi, S. T. Ramesh, P. V. Nidheesh, Journal of Environmental Management, 210 (2018) 328-337. https://doi.org/10.1016/i.jenvman.2018.01.019

[17] H. Zhang, X. Ran, X. Wu, Journal of Hazardous Materials 241-242 (2012) 259-266. https://doi.org/10.1016/j.jhazmat.2012.09.040

[18] C. T. Wang, W. L. Chou, M. H. Chung, Y. M. Kuo, Desalination 253(1-3) (2010) 129-134. https://doi.org/10.1016/i.desal.2009.11.020

[19] P. V. Nidheesh, R. Gandhimathi, Desalination 299 (2012) 1-15. https://doi.org/10.1016/ j.desal.2012.05.011

[20] H. Olvera-Vargas, X. Zheng, O. Garcia-Rodriguez, O. Lefebvre, Water Research 154 (2019) 277-286. https://doi.org/10.1016/i.watres.2019.01.063

[21] M. Y. A. Mollah, R. Schennach, J. R. Parga, D. L. Cocke, Journal of Hazardous Materials 84(1) (2001) 29-41. https://doi.org/10.1016/S0304-3894(01)00176-5

[22] M.J. Bashir, J.H. Lim, S. S. A. Amr, L. P. Wong, Y. L. Sim, Journal of Cleaner Production 208 (2020) 716-727. https://doi.org/10.1016/i.jclepro.2018.10.073 
[23] C. Comninellis, G. Chen (Eds.), Electrochemistry for the Environment, Springer, London, 2008.

[24] A. Akyol, O. T. Can, E. Demirbas, M. Kobya, Separation and Purification Technology 112 (2013) 11-19. https://doi.org/10.1016/i.seppur.2013.03.036

[25] F. C. Moreira, R. A. R. Boaventura, E. Brillas, V. J. P. Vilar, Applied Catalysis B: Environmental 202 (2017) 217-261. https://doi.org/10.1016/i.apcatb.2016.08.037

[26] G. Moussavi, M. Aghanejad, Separation and Purification Technology 132 (2014) 182-186. https://doi.org/10.1016/i.seppur.2014.05.007

[27] I. A. Alaton, S. Teksoy, Dyes and Pigments 73(1) (2007) 31-39. https://doi.org/10.1016/ j.dyepig.2005.09.027

[28] S. Sharma, H. Simsek, Chemosphere 221 (2019) 630-639. https://doi.org/10.1016/i.chemo sphere.2019.01.066

[29] I. Khatri, S. Singh, A. Garg, Journal of Environmental Chemical Engineering 6(6) (2018) 73687376. https://doi.org/10.1016/i.jece.2018.08.022

[30] S. Suhartana, P. Purwanto, A. Darmawan, Journal of Physics: Conference Series 1524 (2020) 012086. http://dx.doi.org/10.1088/1742-6596/1524/1/012086

[31] P. Purwanto, R. Riska, Journal of Physics: Conference Series 1295 (2019) 012045. http://dx.doi.org/10.1088/1742-6596/1295/1/012045

[32] A. Babuponnusami, K. Muthukumar, Chemical Engineering Journal 183 (2012) 1-9. https://doi.org/10.1016/i.cej.2011.12.010

[33] Z. I. Abbas, A. S. Abbas, Journal of Environmental Chemical Engineering 7(3) (2019) 103108. https://doi.org/10.1016/j.jece.2019.103108

[34] E. Marlina, P. Purwanto, E3S Web of Conferences 125 (2019) 03003. https://doi.org/ 10.1051/e3sconf/201912503003

[35] F. G. Camacho, P. A. Latoh de Souza, M. L. Martins, C. Benincá, E. F. Zanoelo, Journal of Electroanalytical Chemistry 865 (2020) 114163. https://doi.org/10.1016/i.jelechem. $\underline{2020.114163}$

[36] E. Atmaca, Journal of Hazardous Materials 163(1) (2009) 109-114. https://doi.org/10.1016/ j.jhazmat.2008.06.067

[37] M. Panizza, M. Delucchi, A. Giuliano, G. Cerisola, A. Barbucci, M. P. Carpanese, M. CataldoHernández, Separation and Purification Technology 118 (2013) 394-398. https://doi.org/ 10.1016/j.seppur.2013.07.023

(C)2021 by the authors; licensee IAPC, Zagreb, Croatia. This article is an open-access article distributed under the terms and conditions of the Creative Commons Attribution license (https://creativecommons.org/licenses/by/4.0/) 